\title{
TOP MANAGEMENT TEAM COMPOSITION AND FINANCIAL PERFORMANCE: EXAMINING THE ROLE OF GENDER DIVERSITY
}

\author{
Dana Egerová, Marta Nosková
}

\section{Introduction}

The issue of female representation in top management teams is a growing area of interest among practitioners, policymakers, and researchers around the world (Ahmadi, Nakaa, \& Bouri, 2018). In particular, there has been an ongoing debate about whether gender diversity in top management teams relates to company performance, more specifically financial performance (Farag \& Mallin, 2017; Hernandez-Nicolás et al., 2015).

The existing body of literature suggests that top management team gender diversity has both positive and negative effects on company performance. Additionally, the results of empirical studies on this issue remain mixed (e.g., Ali \& Konrad, 2017; Eger \& Indruchová, 2014; Julizaerma \& Sori, 2012). On the one hand, there is evidence that gender diversity in top management is associated with higher financial performance (e.g., Campbell \& Mínguez-Vera, 2008; Perryman, Fernando, \& Tripathy, 2016). On the other hand, the results gained by another survey report negative or no relationship between gender diversity in top management teams and company financial performance (e.g., Adams \& Ferreira, 2009; Chapple \& Humphrey, 2014; Wang \& Clift, 2009).

Most research surveys investigating the effect of top management team characteristics on company performance implicitly or explicitly draw on the upper echelon theory (Plöckinger et al., 2016). The upper echelon theory emphasizes the critical role of top management teams on organizational strategic decisions and performance (Hambrick \& Mason, 1984). The theory further states that top managers' observable and unobservable background characteristics play a significant role in organizational decision-making and ultimately in organizational outcomes (Hambrick, 2007). Thus, to explain organizational outcomes and eventually financial outcomes, it is necessary to consider the characteristics of the top management team. This survey is therefore aimed to identify the possible link between company financial performance and top managerial team composition based on gender representation.

Furthermore, previous empirical surveys and existing literature explore the link between gender diversity in top management teams and financial outcomes predominantly in large organizations, while only a few studies are conducted in small- and medium-sized enterprises (Dale-Olsen, Schone, \& Verner, 2013; Mínguez-Vera \& Martin, 2011; Ward \& Forker, 2015). However, small- and mediumsized enterprises are considered to be crucial engines for economic growth throughout the world. Small- and medium-sized enterprises represent over $95 \%$ of enterprises in most OECD countries, $99 \%$ in the $\mathrm{EU}$, and $99.8 \%$ in the Czech Republic (Eurostat, 2017). Hence, some authors (e.g., Francoeur, Labelle, \& SinclairDesgagné, 2007) call for an examination of this issue in small- and medium-sized organizations instead of only in large ones. We respond to this call by focusing our study on small- and medium-sized enterprises.

With regard to debates about women's representation in top management teams, the importance of a certain number or percentage of women in the top management team (TMT) is often stressed. This raises questions such as, what is the number or percentage of women in top management teams influencing financial performance? More specifically, what proportion of women in top management is likely to constitute a critical mass that contributes to better financial performance? As stated by Charles, Redor and Zopounidis (2015), most studies have typically focused on the impact of the presence of women on 
financial performance; however, based on critical mass theory, the mere presence of women on boards may not be sufficient to bring a positive impact. Furthermore, shifting the debate from the presence of women in top management teams to the size of the minority group (the number of women in TMT) enabled an understanding of the importance of top management team processes (Torchia, Calabro, \& Huse, 2011).

Furthermore, authors Konrad, Kramer, and Erkut (2008) call to shift research solely focused on women's presence in top management teams to the proportion of female top management membership expressed by the number/percentage of women in top management teams. Similarly, Kirsch (2017) suggests paying close attention to threshold effects, such as the shift from zero to one-woman directors to a critical mass of women directors. In doing so, unlike prior surveys in terms of measurements, this study uses the number/percentage of women in top management as the independent variable and critical mass is investigated. Thus, the present study contributes to the debate on the relationship between top management gender diversity and financial performance by further exploring the critical mass theory.

Under the above-mentioned framework, the purpose of the present study is to explore the relationship between gender diversity in top management teams and the organizational financial performance in small- and mediumsized enterprises in the context of the Czech Republic. Specifically, we investigate what proportion of women (what constitutes critical mass) in top management teams is likely to influence company financial performance. The theoretical framework guiding this study includes the upper echelon theory and the critical mass theory.

The paper is organized as follows. The first section presents the theoretical framework regarding the upper echelon theory and the critical mass theory. An overview of existing empirical research (of the previous findings) is also included. Next, the research design is described, which contains a description of the data and indicators measurement. Next, we present and discuss the results. Finally, the conclusions and limitations of the study are provided.

\section{Theory Background and Research Questions}

\subsection{Upper Echelon Theory}

As previously mentioned, our research investigates the link between gender diversity at top management and financial performance based upon upper echelon employed by Hambrick and Mason (1984). The theory inspired many studies focused on top management teams and helped to understand the causal link between top management characteristics and organizational performance. Empirical studies that followed from Hambrick and Mason's (1984) upper echelon theory suggest that indeed, TMT matters to organizational outcomes (Oppong, 2014). Plöckinger et al. (2016) noted that existing empirical studies in financial research have explicitly (e.g., Nielsen \& Nielsen, 2013; Opstrup \& Villadsen, 2014) or implicitly (e.g., Campbell \& Mínguez-Vera, 2008; Conyon \& He, 2017; Richard, Kirby, \& Chadwick, 2013) drawn on the main assumption of the upper echelon theory. Similarly, Nishii, Gotte, and Raver (2007) argue that several studies analyse the effect of upper echelon characteristics and organizational performance.

The upper echelons theory emphasizes the dominant role of top management teams and the critical impact they have on organizational outcomes. More specifically, the theory states that the organization's outcomes are a reflection of its top managers (Cannella, 2001; Hambrick \& Mason, 1984). The core of upper echelons theory is based on the following two interconnected parts: (1) executives act on the basis of their personalized interpretations of situations they face and (2) this personalized construal is a function of their experiences, values, and personalities. The theory also suggests that demographic characteristics of executives could be used as valid, although incomplete and imprecise, indicators or proxies for more elusive psychological properties and executive dispositions (Cannella, 2001; Hambrick, 2007). Thus, if we want to understand why organizations do the things they do and perform the way they do, emphasis should be placed on the demographic characteristics of their top executives (Carpenter, Geletkanycz, \& Sanders, 2004; Hambrick, 2007).

Next, the important feature of upper echelons theory is a focus on the top management team rather than strictly on single 
chief executives (Finkelstein \& Hambrick, 1990). Hambrick (2007) noted that focus on executive groups, rather than on individuals, often brings better explanations of organizational outcomes. Thus, as argued by Finkelstein and Hambrick (1990), if we want to understand organizational outcomes, we need to look not just at the CEO, but rather at the entire top management team.

An issue that needs to be also considered is top management team diversity (TMT), which is considered as one of the fundamental upper echelons constructs (Hambrick, Cho, \& Chen, 1996; Hambrick, Humphrey, \& Gupta, 2015). Previous studies have reported mixed and often contradictory results of TMT diversity on performance ranging from a positive relationship between TMT diversity and financial performance through to an insignificant to negative association between TMT diversity and financial performance (Dwyer, Richard, \& Chadwick, 2003; Post \& Byron, 2015; Roberson \& Hyeon, 2007). A possible explanation for the conflicting results may be due to the fact that, TMT diversity is defined mostly as a general construct (Nielsen, 2010). As noted by Nielsen and Nielsen (2013), dealing with diversity as a generic unidimensional concept does not reflect its complex nature and impact. Furthermore, not all aspects of diversity influence team decision-making and company performance in the same way (Nielsen, 2010). Therefore, the author suggests breaking down the construct of diversity into single attributes and consider various diversity attributes independently. According to Krishnan and Park (2005), gender is a more complex demographic variable than other variables and an important measure of diversity. We therefore focus the research on gender in top management teams and investigate whether it enhances company financial performance.

With regard to the above, we argue that the upper echelon theory provides a suitable theoretical framework from which we can examine how management executives and demographic diversity, specifically gender diversity, are related to financial performance in small and medium-sized enterprises. Therefore, under the upper echelon theory framework, we posit the following research question:

Q1: Does gender diversity in top management teams positively affect financial performance in small- and medium-sized enterprises?

\subsection{Critical Mass Theory}

Most previous studies investigating the relationship between gender diversity in top management and firm performance have focused on the impact of the presence of women on financial performance; however, based on the critical mass theory, the mere presence of women on boards may not be sufficient enough to bring significant changes to top management teams and improve corporate governance (Charles, Redor, \& Zopounidis, 2015). According to the critical mass theory, the proportion of socially and culturally diverse people in a group is considered as critical in shaping group dynamics and processes (Kanter, 1977). On the basis of varying proportional compositions, Kanter (1977) identified the following four types of groups: uniform, skewed, titled, and balanced. Uniform includes only one type of people; all members share the same (visible) characteristics. The typological ratio of this group is $100: 1$. With respect to gender, all members of the group are either male or female. Skewed with large dominance of one type over another, the members of the minority (called tokens) become symbolic representatives of their group. This minority group is not able to overcome the problems of tokenism; the ratio of a dominant group to a minority group becomes $85: 15$. With respect to gender, the male dominated skewed group consists of up to $20 \%$ women. Tilted, with less extreme distributions, minority members can form alliances; the ratio of this group is $65: 35$ (up to $40 \%$ ). With respect to gender, a male dominated tilted group consists of 20 to $40 \%$ women. When balanced, there are opportunities to eliminate the majority and gender-based differences in interaction; the ratio of this group is approximately 60:40 down to 50:50 (more than 40\%). With respect to gender representation, this group has 40 to $60 \%$ women (Kanter, 1977; Low, Roberts, \& Whiting, 2015; Torchia, Calabro, \& Huse, 2011). Thus, by shifting the minority size group, it is unlikely that the impact of this subgroup becomes pronounced on group interaction and processes (Broome, Conley, \& Kimberly, 2011).

At the same time, the critical mass theory predicts that when the size of the minority group reaches a certain threshold or critical mass, the influence of the group grows (Konrad, Kramer, \& Erkut, 2008). By analogy, it should be said that when women reach a certain threshold, their influence in top management teams 
grows. On the other hand, the theory does not suggest which number is likely to constitute a critical mass (Torchia, Calabro, \& Huse, 2011). Therefore, studies drawing on the critical mass theory have been conducted to investigate which number is likely to constitute a critical mass of women in top management teams. For example, research by Konrad and Kramer (2006) showed that a critical mass is formed with three or more women. Similarly, Liu, Wei, and Xie (2014) found that a critical mass of three or more women can cause a significant change in managerial teams and improve corporate governance. These authors also identified that boards with three or more female directors have a much stronger impact on company performance than boards with two or fewer women.

Furthermore, using a data set of 151 listed German firms, Joecks, Pull, and Vetter (2013) provided evidence of the critical mass of female representatives on the board to be reached at a share of approximately $30 \%$. On the other hand, the results of the study performed by Kramaric and Miletic (2017) show that when a critical mass of $20-40 \%$ women on the management board has been reached, bank performance improves. In contrast, the study conducted by Lortie-Lussier and Rinfret (2002) did not support the critical mass theory. Additionally, the results obtained by Charles, Redor and Zopounidis (2015) reported that there are no significant inferences in firm performance between firms with and without a critical mass of women on their boards. Overall, these empirical results provide opportunity for deeper investigation of critical mass. Therefore, under the critical mass theory framework, we posit the following research question:

Q2: What percentage of women in top management teams constitutes a critical mass that positively influences financial performance in small- and medium-sized enterprises?

\section{Data and Methodology}

\subsection{Data}

The dataset for this study is based on the 823 enterprises of the manufacturing industry in the Czech Republic. The manufacturing industry was selected because it is the industry with the largest production in the Czech Republic and thus is the most important industry of the Czech economy. Only enterprises with 50 to 250 employees were selected to ensure that only small and middle-sized enterprises would be part of the analysis. Additionally, to include only profit-based enterprises, their legal forms were determined as follows: individual entrepreneurs, partnerships, companies with limited liability, and public limited companies. From a total of 823 analysed companies, almost $64 \%$ are companies with limited liability, and $34 \%$ are public limited companies. The rest consist of partnerships and individual entrepreneurs (see Tab. 1).

\section{Tab. 1: Legal forms of analysed enterprises}

\begin{tabular}{c|c|c|c|c}
$\begin{array}{c}\text { Company with Limited } \\
\text { Liability }\end{array}$ & $\begin{array}{c}\text { Public Limited } \\
\text { Company }\end{array}$ & Partnership & $\begin{array}{c}\text { Individual } \\
\text { Entrepreneurs }\end{array}$ & Total \\
\hline 528 & 285 & 5 & 5 & 823 \\
\hline $64.16 \%$ & $34.63 \%$ & $0.61 \%$ & $0.61 \%$ & $100 \%$ \\
\hline
\end{tabular}

In this study we do not consider the time as a variable, thus the data included only one year (2015). To analyse the relationship between gender diversity of senior management and the financial performance of the enterprises, the following data were obtained for each analysed company: name, number of years in business, number of employees, region, total assets, equity, EBIT, EBT, number of senior managers, and number of women in senior management.
These data were mainly obtained from the Bisnode Magnusweb database, which contains comprehensive data on all Czech economic entities, both corporations and individuals. At first, 865 enterprises were found by the database. However, some were excluded from the data set due to missing data or too extreme values. Some missing data were collected from annual reports or enterprise websites. 


\subsection{Indicator Descriptions}

The enterprise's performance is measured in several ways, mostly by using financial indicators. Research examining gender diversity and its influence on the performance of enterprises mostly used market-based measures where Tobin's $Q$ is among the most common (Marinova, Plantenga, \& Remery, 2016; Reguera-Alvarado, de Fuentes, \& Laffarga, 2017; Rodríguez-Domínguez, GarcíaSánchez, \& Gallego-Álvarez, 2012; Pletzer et al., 2015). Accounting-based measures, such as return on assets (ROA), return on equity (ROE) or return on sales (ROS) (Dale-Olsen, Schone, \& Verner, 2013; Sumedrea, 2016) were also used.

In this study, we examine several types of enterprises, most of which are not listed public limited companies. Thus, accountingbased measures such as return on assets (ROA) as the ratio of the enterprise's profit and its total assets (EBIT/total asset) as well as return on equity (ROE) as the ratio of the enterprise's net profit and capital invested by the owner (EBT/Equity) have been used as the most appropriate enterprise performance measurements. Another reason is the fact that managers are able to influence the size of asset, its use, and thus, the final value of EBIT (earnings before interest and taxes). Similarly, for ROE, EBT (earnings before taxes) can also be influenced by management decisions, and the indicator shows how successfully the enterprise is managed.

To prove the relationship between financial performance and the number of women in senior management teams, the indicator PWOMAN was compiled (the percentage of women in the top management team of the enterprise). In addition to this indicator, the following indicators were also selected to examine other relationships to PWOMAN: age of enterprise (AGE), total assets of the enterprise (SIZE), and number of employees (EMP).

\subsection{Methods}

Studies dealing with gender diversity in TMT use several research methods. The most commonly used are the following: panel data analysis (e.g., Dale-Olsen, Schone, \& Verner, 2013; Perryman, Fernando, \& Tripathy, 2016), meta-analysis (Pletzer et al., 2015), creation of the regression model (Ahmadi, Nakaa, \& Bouri, 2018; Reguera-Alvarado, de Fuentes, \&
Laffarga, 2017) or calculation of basic correlation and descriptive statistics (Julizaerma \& Sori, 2012; Sumedrea, 2016). To describe basic characteristics of the sample, the data were analysed by using simple statistical tools such as the mean, median and standard deviation. To reveal basic relationships between indicators, the correlation matrix based on the calculation of Spearman's correlation coefficients was used.

Namely, the k-means method by MacQueen (1967), Lloyd (1982) was used. This method divides $\mathrm{n}$ observations into $\mathrm{k}$ clusters, where each observation belongs to the cluster with the nearest average. Thus, the calculation is performed by several repeated iterative steps. First, it is necessary to determine the number of clusters. If the author does not have any external information that could help to determine the number in advance, it is advisable to attempt the calculation several times with different numbers of clusters and then determine the optimal number. After dividing data into clusters, it is necessary to calculate the value of the centroid (centre of gravity), which represents the average of the data values in a given cluster. Then, values of individual data are compared to the values of their centroids (using Euclidean distance), and if there is a shorter distance to the centroid of a different cluster, new re-allocation of the data is made. After that, new calculations of centroid values must be completed, and the whole process is repeated until data shifts stop. Distribution of data into the clusters was performed using the program STATISTICA 12 StatSoft CR, s. r. o.

\section{Results and Discussion}

\subsection{Descriptive Statistics}

Tab. 2 presents the basic statistics for our sample. From the descriptive statistics, we observe that the mean percentage of women in top management teams (PWOMAN) for the whole sample is approximately $10.14 \%$. This is close to the values obtained by Julizaerma and Sori (2012), who reported a mean of $10.6 \%$ (women proportion in board) using a sample of 280 enterprises in 2008 and 2009. However, the proportion of women in the boards is usually lower, for example Campbell and MínguezVera (2008) report a value of $3.2 \%$, Marinova, Plantenga, and Remery (2016) a value of $5.4 \%$, Perryman, Fernando and Tripathy (2016) a value of $4.8 \%$, or Reguera-Alvarado, de 


\section{Business Administration and Management}

Fuentes and Laffarga (2017) a value of $6.92 \%$. In addition, in terms of the percentage of females in top management teams, there were 232 enterprises with at least one woman in the top management team. In total, there were 423 women in top management teams in these 232 enterprises, and the average percentage of females in top management teams in this group of enterprises was $34.5 \%$. In terms of age, the average value was 20.34 , with the maximum being 29 , and the median being 22 years. This value is in line with the mean value of 22.58 years in business reported by Julizaerma and Sori (2012) amongst Malaysian firms.

It may seem that enterprises in the Czech Republic are relatively young for example, in comparison to the mean value of 56.77 years reported by Sumedrea (2016) amongst Romanian companies, this is caused by the transformation of Czech economy in early 1990 (after the collapse of communist regime) when many state enterprises changed their form, and even more enterprises were founded. Thus, the oldest enterprises included in the analysis were founded in 1988 and the youngest in 2014. In terms of size, there are large differences in the values of assets with a standard deviation of 321.520 million (Czech crowns). The number of employees was determined in advance with a minimum of 50 and maximum of 249 similarly to Mínguez-Vera and Martin (2011). The Bisnode Magnusweb Database works only with intervals and their centres; thus, in Tab. 2, the minimum is 75 employees, and the maximum is 225 . The enterprises with 100-199 employees are dominant (388 enterprises), the second are those with 50-99 employees (339 enterprises), and the least represented group are enterprises with 200-249 employees (96 enterprises). As far as financial indicators are concerned, the average $\mathrm{ROA}$ is $8.33 \%$ with a median of $6.92 \%$ and the maximum ROA is $79.47 \%$, while the minimum is $-44.26 \%$. For comparison, Pletzer et al. (2015), who analysed 10 studies where ROA was the main indicator of financial performance, reported that its value is mostly lower than $8.24 \%$. The average ROE is $14.94 \%$ with a median $12.14 \%$; the maximum value is $172.17 \%$, while the minimum is $-139.96 \%$. Value reported in this study is slightly lower than $19.81 \%$ reported by Ahmadi, Nakaa, and Bouri (2018), but in line with already mentioned Pletzer et al. (2015), who found four studies with the following ROE values: $15.27 \%, 14.91 \%, 9.92 \%$ and $6.73 \%$. The present values indicate that there are both successful and less successful enterprises in our sample.

\section{Tab. 2: Descriptive statistics}

\begin{tabular}{l|c|c|c|c|c} 
& Mean & Median & Standard deviation & Min & Max \\
\hline PWOMAN & $10.14 \%$ & 0 & $18.62 \%$ & 0 & $100 \%$ \\
\hline AGE & 20.34 & 22 & 5.38 & 3 & 29 \\
\hline SIZE & $269,075,255$ & $173,155,000$ & $321,519,624$ & $19,244,000$ & $4,119,226,000$ \\
\hline EMP & 127.84 & 150 & 49.85 & 75 & 225 \\
\hline ROA & $8.33 \%$ & $6.92 \%$ & $10.40 \%$ & $-44.26 \%$ & $79.47 \%$ \\
\hline ROE & $14.94 \%$ & $12.14 \%$ & $23.79 \%$ & $-139.96 \%$ & $172.17 \%$ \\
\hline
\end{tabular}

\subsection{Correlation Analysis}

To investigate the possible link between enterprises' financial performance and top management team composition based on gender representation, Spearman's correlation coefficients for all indicators were first calculated (see Tab. 3). Correlations that are significant at the level of $p<0.5$ are marked with an asterisk $\left(^{*}\right)$. A statistically significant positive correlation possesses ROA and ROE,
ROE and size, as well as size and number of employees. A statistically significant negative correlation can be found between ROE and age, while other correlations are insignificant.

Due to the construction of ROA and ROE, it is no surprise that there is a positive correlation observed (the same finding reported GallegoÁlvarez, García-Sánchez, \& RodríguezDomínguez, 2010). Additionally, the same significant positive correlation applies to ROA 
and size, which is consistent with the results of Sumedrea (2016). A positive significant correlation was also found between the number of employees and size of the enterprise, which means that the higher the number of employees, the higher the assets of the enterprise. EMP indicator is not usually part of these analysis, however significant correlation between size (expressed by total assets) and board size can be often observed (e.g., Julizaerma \& Sori, 2012; Rodríguez-Domínguez, GarcíaSánchez, \& Gallego-Álvarez, 2012; Sumedrea, 2016). A significant negative correlation can be observed between age and ROE, which indicates a greater ability of young enterprises to appreciate invested capital. This result is similar to the one obtained by Low, Roberts, and Whiting (2015).

The indicator reflecting the presence of women in top management teams shows a positive correlation with financial indicators ROA and ROE as well as size and number of employees, but only the correlation between the presence of women in TMT and size appears to be significant. In contrast, the presence of women in TMT is slightly negatively related to age.
A possible explanation for this is the fact that in younger firms, women have an easier entry into top management teams. The correlation between the presence of women in TMT and ROA, is considered as the most important correlation in this study, however it is insignificant. The same result was observed by e.g., Gallego-Álvarez, García-Sánchez and Rodríguez-Domínguez (2010), Julizaerma and Sori (2012) or Richard, Kirbyand, and Chadwick (2013). As Julizaerma and Sori (2012) suggest, it can be caused by few female directors in the sample. Thus, other analysis has to be performed.

To examine the link between enterprises' financial performance and the presence of women in top management teams more closely, it was necessary to look into the values of indicators for the groups of enterprises with one or more women in the top management team and enterprises with no women in the top management team. Thus, we calculated the average value of all analysed indicators after grouping the enterprises into the following 2 groups: one with no women in the top management team and the second with one or more women in the top management team.

\section{Tab. 3: Spearman's correlation coefficients matrix}

\begin{tabular}{l|r|r|r|r|r|r} 
& AGE & EMP & \multicolumn{1}{c|}{ SIZE } & PWOMAN & ROE & ROA \\
\hline AGE & 1.000 & 0.064 & 0.026 & -0.045 & ${ }^{*}-0.130$ & -0.055 \\
\hline EMP & 0.064 & 1.000 & ${ }^{*} 0.440$ & 0.064 & -0.016 & -0.012 \\
\hline SIZE & 0.026 & ${ }^{*} 0.440$ & 1.000 & ${ }^{*} 0.092$ & 0.015 & ${ }^{*} 0.071$ \\
\hline PWOMAN & -0.045 & 0.064 & ${ }^{*} 0.092$ & 1.000 & 0.031 & 0.004 \\
\hline ROE & ${ }^{*}-0.130$ & -0.016 & 0.015 & 0.031 & 1.000 & ${ }^{*} 0.860$ \\
\hline ROA & -0.055 & -0.012 & ${ }^{*} 0.071$ & 0.004 & ${ }^{*} 0.860$ & 1.000 \\
\hline
\end{tabular}

Note: * significant at $p<0.5$

\begin{tabular}{|c|c|c|c|c|c|c|}
\hline & $\begin{array}{l}\text { Number of } \\
\text { enterprises }\end{array}$ & ROA & ROE & SIZE & EMP & AGE \\
\hline All enterprises & 823 & $8.33 \%$ & $14.94 \%$ & $269,075,255$ & 127.84 & 20.34 \\
\hline $\begin{array}{l}\text { Enterprises with one or } \\
\text { more women at TMT }\end{array}$ & 232 & $8.74 \%$ & $17.28 \%$ & $335,515,789$ & 134.75 & 19.95 \\
\hline $\begin{array}{l}\text { Enterprises with no women } \\
\text { at TMT }\end{array}$ & 591 & $8.17 \%$ & $14.02 \%$ & $242,993,692$ & 125.17 & 20.49 \\
\hline
\end{tabular}




\section{Business Administration and Management}

From the figures in Tab. 4, it is evident that enterprises with one or more women in the top management team present a higher level of financial performance as measured by ROA and ROE than those with no women in the top management team. More accurately, enterprises with one or more women outperform enterprises that do not have any female directors by a mean of $0.57 \%$ in ROA and $3.26 \%$ in ROE. The greater difference in ROE may indicate better use of equity in enterprises with managerial gender diversity. These findings are consistent with the findings of existing studies (Ahmadi, Nakaa, \& Bouri, 2018; Julizaerma \& Sori, 2012; Liu, Wei, \& Xie, 2014; Low, Roberts, \& Whiting, 2015) showing that companies with women in top managerial teams perform better than those without women in the managerial team. Despite the fact that the relationship between the percentage of females in TMT and ROA is small, the overall findings support the idea that the presence of women in management would benefit financial performance.

In addition, the average values indicate that the group of enterprises with gender diversity in the top management team have more assets and more employees. Moreover, this group of enterprises is slightly younger than the enterprises without women in the top management team. The same finding was observed by Sumedrea (2016), who proved that older companies have more masculine management teams.

\subsection{Cluster Analysis}

To further clarify the relationships between all indicators, cluster analysis was conducted for the group of 232 enterprises with top management team diversity. As mentioned above, clusters are compiled where each observation belongs to the cluster with the nearest average, and the clusters are concurrently set as far apart from each other as possible. It was decided that there would be three clusters (see Tab. 5). In cluster number one, there are enterprises that differ considerably from each other in terms of size, age, and the highest average value of ROE (in comparison to the lowest values of PWOMAN). However, since the first cluster contains only four enterprises, they should be seen as a group of exceptions that formed an individual cluster. If these four enterprises were included in other clusters, they could considerably distort their average values. The other two clusters are more significant; cluster 2 with 43 enterprises and cluster 3 with 185 . The second cluster contains enterprises with the highest values of assets and the highest ROA. The third cluster contains enterprises with the lowest value of assets, the lowest number of employees, the highest portion of women in top management teams, and the highest ROE.

When analysing average values of ROE, ROA, and PWOMAN using the results of clusters 2 and 3 , a positive relationship can be seen between PWOMAN and ROE. The higher the PWOMAN, the higher the ROE. On the other hand, ROA is higher in the cluster with the lower PWOMAN, which denies the previously observed results. However, in cluster 3 , ROA shows its average value (compare with Tab. 2). Thus, the cause of the illogical result lies in cluster 2 , where there are only 43 enterprises. With this low number of enterprises, the average can be easily distorted by higher values. Namely, there

\section{Tab. 5: Average characteristics of indicators in individual clusters}

\begin{tabular}{l|c|c|c} 
& Cluster 1 & Cluster 2 & Cluster 3 \\
\hline Number of enterprises & 4 & 43 & 185 \\
\hline AGE & 18.75 & 20.58 & 19.83 \\
\hline EMP & 188 & 161 & 128 \\
\hline SIZE & $281,652,500$ & $735,050,100$ & $189,007,600$ \\
\hline PWOMAN & $25.89 \%$ & $30.97 \%$ & $37.37 \%$ \\
\hline ROE & $18.88 \%$ & $15.66 \%$ & $17.62 \%$ \\
\hline ROA & $8.14 \%$ & $10.35 \%$ & $8.38 \%$
\end{tabular}


Tab. 6: Values of financial performance indicators grouped according to PWOMAN

\begin{tabular}{|c|c|c|c|c|c|c|c|}
\hline $\begin{array}{l}\text { PWOMAN } \\
(\%)\end{array}$ & $\begin{array}{l}\text { Number of } \\
\text { enterprises }\end{array}$ & $\begin{array}{l}\text { Median } \\
\text { ROE }\end{array}$ & $\begin{array}{l}\text { Min } \\
\text { ROE }\end{array}$ & $\begin{array}{l}\text { Max } \\
\text { ROE }\end{array}$ & $\begin{array}{c}\text { Median } \\
\text { ROA }\end{array}$ & $\begin{array}{l}\text { Min } \\
\text { ROA }\end{array}$ & $\begin{array}{l}\text { Max } \\
\text { ROA }\end{array}$ \\
\hline 0 & 591 & 11.95 & -139.96 & 125.96 & 8.17 & -44.26 & 79.47 \\
\hline $10-20$ & 53 & 9.60 & -24.77 & 103.01 & 5.62 & -20.81 & 51.94 \\
\hline $21-30$ & 44 & 11.24 & -21.54 & 48.81 & 6.00 & -7.46 & 38.47 \\
\hline $31-40$ & 71 & 14.71 & -35.39 & 172.17 & 8.67 & -16.72 & 55.67 \\
\hline $41-50$ & 35 & 11.26 & -23.85 & 75.68 & 6.46 & -11.86 & 64.04 \\
\hline $51-100$ & 29 & 12.84 & -0.49 & 71.02 & 7.80 & 0.16 & 37.19 \\
\hline
\end{tabular}

are three enterprises with considerably high ROA $(64 \%, 29.7 \%$ and $25.2 \%)$ values. These enterprises were likely included by STATISTICA into cluster 2 mainly due to their high value of assets. If these three enterprises were excluded from this cluster, the average ROA decreases to $8.3 \%$, while the ROE decreases only to $14.07 \%$ and PWOMAN to $30 \%$. Additionally, this analysis confirms a positive relationship between PWOMAN and ROA.

To identify the critical mass (ratio of women in top management teams), Tab. 6 was compiled. It contains data from 232 enterprises with top management team diversity.

First, the results show that the enterprises with a proportion of women in TMT from $10 \%$ to $20 \%$ have lower median ROE and ROA than the enterprises with no women in TMT. These findings are consistent with Kanter's (1977) theory of tokenism. Contrary to Kanter's proportion of token group (up to $20 \%$ of minority group), we find that ROE and ROA medians are also lower in the group of enterprises with proportions from $21 \%$ to $30 \%$ compared to the group of enterprises without gender diversity in TMT. A possible explanation for this is the issue of the moderating effect of cultural values, more specifically of conservative values, which are still dominant in our context. Moreover, stereotyping views against women, especially in managerial and executive positions, is also a possible moderating factor. Surprisingly, a similar finding was also identified for the group of enterprises with the proportion from $41 \%$ to $50 \%$. These findings are similar to those in the group with the proportion from $21 \%$ to $30 \%$. One interpretation for this is the growing threat of male dominance due to increasing gender equality and thereby defensive behaviour (Blalock, 1967; Yoder, 1991). Next, the most positive impact for ROE and ROA was found in the group of enterprises with the proportion of $31 \%$ to $40 \%$ females in TMT. Therefore, our conclusion is that critical mass of female representatives in top management teams is reached at a share of approximately $31 \%$ to $40 \%$ for our sample.

\section{Conclusion}

In this study, the upper echelon theory and the critical mass theory are combined to provide theoretical insight and empirical analysis of gender diversity in top management teams on company financial performance. Under the upper echelon theory framework, which proposes positive relationships between variety of TMT demographic characteristic and company performance (Carpenter, Geletkanycz, \& Sanders, 2004; Hambrick \& Mason, 1984), we investigated whether female participation in top management teams positively influences company financial performance. Based on the critical mass theory proposing that women are unlikely to have a positive impact in top management teams until they rise up from a few tokens into a considerable minority in top management, we tried to determine what percentage of women in top management teams constitute critical mass. Unlike previous studies (Ali, Ng, \& Kulik, 2014; Low, Roberts, \& Whiting, 2015; Richard, Kirby, \& Chadwick, 2013; Ward \& Forker, 2015), both theories were applied to only the context of small and medium enterprises in the manufacturing sector.

The study found that, on average, enterprises with women in top management 
teams obtain better financial performance as measured by accounting-based measures such as ROA and ROE than companies without women in top management teams. These findings demonstrate that gender diversity in top management teams (measured by the percentage of women) has a positive impact on firm financial performance. Thus, in line with previous studies (Campbell \& MínguezVera, 2008; Conyon \& He, 2017), we argue that top management teams should include both men and women, since the TMT's gender diversity seems to positively influence enterprise financial performance. Furthermore, the study offers new insight into the relationship between top management gender diversity and company financial performance by using data from SMEs.

As noted previously, our study was also guided by the following research question: "What percentage of women in top management teams constitutes a critical mass that positively influences financial performance in small- and medium-sized enterprises?" First, the main finding is that when a critical mass of $31 \%$ to $40 \%$ of women in top management teams is reached, the company financial performance measured by ROA and ROE improves. This finding mostly supports the critical mass theory and previous studies drawing on the critical mass theory (e.g., Konrad, Kramer, \& Erkut, 2008; Liu, Wei, \& Xie, 2014), suggesting that critical mass is approximately $30 \%$. Next, in accordance with the critical mass theory and study by Joecks, Pull, and Vetter (2013), we also find that token top management teams are outperformed by tilted top management teams. However, in contrast to the critical mass theory that proposes token groups up to $20 \%$ (Kanter, 1977), we find the proportion of token groups to be $30 \%$. In our view, issues including national and corporate culture as well as prevailing stereotyping, influence the findings. This explanation is partially supported by Torchia, Calabro, and Huse (2011), who argue that the proportion of tokenism seems to vary from culture to culture. Thus, we argue that cultural factors need to be considered as important variables in studies seeking to measure the effects of women's representation in top management teams on company performance.

Moreover, we find that the balanced group in our sample performs worse than the tilted group. A possible explanation may consider the premise of the Blalock power-threat theory. Based on the theory, we argue that increasing the percentage of women in top management would generate negative behaviour from the majority group (men) to protect their dominant status and as the response to the perceived threat. However, as proposed by Yoder (1991, p. 188), the dominant group can effectively restructure the workplace to reduce the competitive threat posed by the growing minority.

In sum, consistent with the critical mass theory (Kanter, 1977) our findings show that gender diversity in top management teams is positively associated with company financial performance once a critical mass of women in top management team is achieved. The results indicate that gender diversity in top management teams ranking below the critical mass is in fact associated with negative financial performance. At the same time the results also reveal that an increased number of women in top management teams which is above the critical mass leads to a poorer financial performance.

Thus, this study does not support a linear relationship between the number of women in top management teams and financial performance (Campbell, \& Mínguez-Vera, 2008; Perryman, Fernando, \& Tripathy, 2016) and only partially supports a U-shaped relationship (Joecks, Pull, \& Vetter, 2013; Wiley \& Monllor-Tormos, 2018). Furthermore, our findings provide empirical evidence and a rationale for a critical mass of women in top management teams in small- and medium-sized enterprises. The study suggests that the critical mass needed to improve financial performance lies in the range of $31 \%$ to $40 \%$. Therefore, to enhance positive financial performance it is suggested to shareholders and managers of small- and medium-sized enterprises to develop and adopt tailored strategies towards reaching the critical mass of female in top management teams rather than on tokens.

Overall, this study brings new insight to the area of gender diversity in top management and advances the gender diversity literature's understanding of the relationship between top management team composition and financial performance. More specifically, the study provides a better understanding of the key role of a critical mass in top management teams. 


\section{Limitations}

It should be noted that, as in other studies, this study has limitations that point to potentially further research opportunities. First, the current study investigates the influence of gender diversity on company financial performance in only top management teams. To obtain a more complete picture, it might be useful to also analyse this issue in other management levels of the company. Second, the findings are based on research in a specific context of a single industry and may not be generalizable. Thus, cross-industry analyses are needed to strengthen the findings and arguments. Finally, we used data from only one year. Hence, future research should include data covering a longer period to achieve more consistent results.

\section{References}

Adams, R. B., \& Ferreira, D. (2009). Women in the boardroom and their impact on governance and performance. Journal of Financial Economics, 94(2), 291-309. https://doi.org/10.1016/j.jfineco.2008.10.007.

Ahmadi, A., Nakaa, N., \& Bouri, A. (2018). Chief Executive Officer attributes, board structures, gender diversity and firm performance among French CAC 40 listed firms. Research in International Business and Finance, 44, 218-226. https://doi.org/10.1016/j. ribaf.2017.07.083.

Ali, M., \& Konrad, A. M. (2017) Antecedents and consequences of diversity and equality management systems: The importance of gender diversity in the TMT and lower to middle management. European Management Journal, 35(4), 440-453. https://doi.org/10.1016/j. emj.2017.02.002.

Ali, M., Ng, Y. L., \& Kulik, C. T. J. (2014). Board Age and Gender Diversity: A Test of Competing Linear and Curvilinear Predictions. Journal of Business Ethics, 125(3), 497-512. https://doi.org/10.1007/s10551-013-1930-9.

Blalock, H. (1967). Toward a Theory of Minority-Group Relations. New York: John Wiley.

Broome, L. L., Conley, J. M., \& Kimberly, D. K. (2011). Does Critical Mass Matter? Views from the Board Room. Seattle University Law Review, 34, 1049-1080.

Campbell, K., \& Mínguez-Vera, A. (2008). Gender diversity in the boardroom and firm financial performance. Journal of Business
Ethics, 83(3), 435-451. https://doi.org/10.1007/ s10551-007-9630-y.

Cannella Jr., A. A. (2001). Upper echelons: Donald Hambrick on executives and strategy. Academy of Management Perspectives, 15(3), 36-42. https://doi.org/10.5465/ ame.2001.5229499.

Chapple, L., \& Humphrey, J. E. (2014). Does Board Gender Diversity Have a Financial Impact? Evidence Using Stock Portfolio Performance. Journal of Business Ethics, 122(4), 709-723. https://doi.org/10.1007/ s10551-013-1785-0.

Charles, A., Redor, E., \& Zopounidis, C. (2015). The determinants of the existence of a critical mass of women on boards: A discriminant analysis. Economics Bulletin, 35(3), 185-197.

Carpenter, M. A., Geletkanycz, M. A., \& Sanders, Wm. G. (2004). Upper Echelons Research Revisited: Antecedents, Elements, and Consequences of Top Management Team. Journal of Management, 30(6), 749-778. https://doi.org/10.1016/j.jm.2004.06.001.

Conyon, M. J., \& He, L. (2017) Firm performance and boardroom gender diversity: A quantile regression approach. Journal of Business Research, 79, 198-211. https://doi. org/10.1016/j.jbusres.2017.02.006.

Dale-Olsen, H., Schone, P., \& Verner, M. (2013). Diversity among Norwegian boards of directors: Does a quota for women improve firm performance? Feminist Economics, 19(4), 110-135. https://doi.org/10.1080/13545701.201 3.830188 .

Dwyer, S., Richard, O. C., \& Chadwick, K. (2003). Gender diversity in management and firm performance: the influence of growth orientation and organizational culture. Journal of Business Research, 56(12), 1009-1019. https://doi.org/10.1016/S0148-2963(01)00329-0.

Eger, L., \& Indruchová, Z. (2014). Diversity management - Perceptions and attitudes by Czech managers. E\&M Ekonomie a Management, 17(1), 73-81. https://doi. org/10.15240/tul/001/2014-1-006.

European Commission. (2017). Report on Equality Between Women and Men. Luxembourg: Publications Office of the European Union. European Commision. Growth-Entrepreneurship and Small and medium-sized enterprises (SMEs). Retrieved November 23, 2017, from http://ec.europa.eu/ growth/smes_en/. 
Eurostat. (2017). Structural Business Statistics - Small and medium-sized enterprises. Retrieved November 23, 2017, from http://ec.europa.eu/eurostat/web/structuralbusiness-statistics/structural-business-statistics/ sme/.

Farag, H., \& Mallin, C. (2017). Board diversity and financial fragility: Evidence from European banks. International Review of Financial Analysis, 49, 98-112. https://doi. org/10.1016/j.irfa.2016.12.002.

Finkelstein, S., \& Hambrick, D. C. (1990). Top-Management-Team Tenure and Organizational Outcomes: The Moderating Role of Managerial Discretion. Administrative Science Quarterly, 35(3), 484-503. https://doi. org/10.2307/2393314.

Francoeur, C., Labelle, R., \& SinclairDesgagné, B. (2007). Gender Diversity in Corporate Governance and Top Management. Journal of Business Ethics, 81(1), 83-95. https://doi.org/10.1007/s10551-007-9482-5.

Gallego-Álvarez, I., García-Sánchez, I., \& Rodríguez-Domínguez, L. (2010). The influence of gender diversity on corporate performance. Revista de Contabilidad-Spanish Accounting Review, 13(1), 53-88. https://doi.org/10.1016/ S1138-4891(10)70012-1.

Hambrick, D. C. (2007). Upper Echelons Theory: An Update. Academy of Management Review, 32, 334-343. https://doi. org/10.2307/20159303.

Hambrick, D. C., Cho, T. S., \& Chen, M. (1996). The influence of top management team heterogeneity on firms' competitive moves. Administrative Science Quarterly, 41(4), 659684. https://doi.org/10.2307/2393871.

Hambrick, D. C., Humphrey, S. E., \& Gupta, A. (2015). Structural interdependence within top management teams: A key moderator of upper echelons predictions. Strategic Management Journal, 36(3), 449-461. https://doi.org/10.1002/smj.2230.

Hambrick, D. C., \& Mason, P. A. (1984). Upper Echelons: The Organization as a Reflection of Its Top Managers. Academy of Management Review, 9(2), 193-206. https://doi.org/10.2307/258434.

Hernandez-Nicolás, M. C., Martín-Ugedo, J. F., \& Mínguez-Vera, A. (2015). The influence of gender on financial decisions: Evidence from small start-up firms in Spain. E\&M Ekonomie a Management, 18(4), 93-107. https://doi. org/10.15240/tul/001/2015-4-007.
Julizaerma, M. K., \& Sori, Z. M. (2012). Gender Diversity in the Boardroom and Firm Performance of Malaysian Public Listed Companies. Procedia - Social and Behavioral Sciences, 65, 1077-1085. https://doi. org/10.1016/j.sbspro.2012.11.374.

Joecks, J., Pull, K., \& Vetter, K. J. (2013). Gender Diversity in the Boardroom and Firm Performance: What Exactly Constitutes a "Critical Mass?" Journal of Business Ethics, 118(1), 61-82. https://doi.org/10.1007/s10551-012-1553-6.

Kanter, R. M. (1977). Some Effects of Proportions on Group Life: Skewed Sex Ratios and Responses to Token Women. American Journal of Sociology, 82(5), 965-990.

Kirsch, A. (2017). The gender composition of corporate boards: A review and research agenda. The Leadership Quarterly, 29(2), 346-364. https://doi.org/10.1016/j.leaqua.2017.06.001.

Konrad, A. M., Kramer, V. W., \& Erkut, S. (2008). Critical Mass: The Impact of Three or More Women on Corporate Boards. Organizational Dynamics, 37(2), 145-164. https://doi.org/10.1016/j.orgdyn.2008.02.005.

Konrad, A. M., \& Kramer, V. W. (2006). How many women do boards need? Harvard Business Review, 84(12), 22.

Kramaric, T. P., \& Miletic, M. (2017). Critical Mass in the Boardroom of Croatian Banks. South East European Journal of Economics and Business, 12(1), 22-37. https://doi.org/10.1515/ jeb-2017-0002.

Krishnan, A., \& Park, D. (2005). A few good women-on top management teams. Journal of Business Research, 58(12), 1712-1720. https://doi.org/10.1016/j.jbusres.2004.09.003.

Liu, Y., Wei, Z., \& Xie, F. (2014). Do women directors improve firm performance in China? Journal of Corporate Finance, 28, 169-184. https://doi.org/10.1016/j.jcorpfin.2013.11.016.

Lloyd, S. P. (1982). Least squares quantization in PCM. IEEE Transactions on Information Theory, 28(2), 129-137.

Lortie-Lussier, M., \& Rinfret, N. (2002). The Proportion of Women Managers: Where Is the Critical Mass? Journal of Applied Social Psychology, 32(9), 1974-1991. https://doi. org/10.1111/j.1559-1816.2002.tb00268.x.

Low, D. C. M., Roberts, H., \& Whiting, R. H. (2015). Board gender diversity and firm performance: Empirical evidence from Hong Kong, South Korea, Malaysia and Singapore. Pacific-Basin Finance Journal, 35(PA), 381-401. https://doi.org/10.1016/j.pacfin.2015.02.008. 
MacQueen, J. B. (1967). Some Methods for classification and Analysis of Multivariate Observations. In Proceedings of 5th Berkeley Symposium on Mathematical Statistics and Probability, University of California Press, 1 (pp. 281-297).

Marinova, J., Plantenga, J., \& Remery, C. (2016). Gender diversity and firm performance: Evidence from Dutch and Danish boardrooms. The International Journal of Human Resource Management, 27(15), 1777-1790. https://doi.org/ 10.1080/09585192.2015.1079229.

Mínguez-Vera, A., \& Martin, A. (2011). Gender and management on Spanish SMEs: An empirical analysis. The International Journal of Human Resource Management, 22(14), 2852-2873. https://doi.org/10.1080/09585192. 2011.599948.

Nielsen, S. (2010). Top Management Team Diversity: A Review of Theories and Methodologies. International Journal of Management Reviews, 12(3), 301-316. https://doi.org/10.1111/j.1468-2370.2009.00263.x.

Nielsen, B. B., \& Nielsen, S. (2013). Top management team nationality diversity and firm performance: A multilevel study. Strategic Management Journal, 34(3), 373-382. https://doi.org/10.1002/smj.2021.

Nishii, L., Gotte, A., \& Raver, J. (2007). Upper echelon theory revisited: The relationship between upper echelon diversity, the adoption of diversity practices, and organizational performance [CAHRS Working Paper \#07-04]. Ithaca, NY: Cornell University, School of Industrial and Labor Relations.

Oppong, S. (2014). Upper echelons theory revisited: The need for a change from causal description to casual explanation. Management: Journal of Contemporary Management Issues, 19(2), 169-183.

Opstrup, N., \& Villadsen, A. R. (2014). The right mix? Gender Diversity in Top Management Teams and Financial Performance. Public Administration Review, 75(2), 291-301. https://doi.org/10.1111/puar.12310.

Perryman, A. A., Fernando, G. D., \& Tripathy, A. (2016). Do gender differences persist? An examination of gender diversity on firm performance, risk, and executive compensation. Journal of Business Research, 69(2), 579-586. https://doi.org/10.1016/j. jbusres.2015.05.013.

Pletzer, J. L., Nikolova, R., Kedzior, K. K., \& Voelpel, S. C. (2015). Does gender matter?
Female representation on corporate boards and firm financial performance - A meta-analysis. PloS One, 10(6), 1-20. https://doi.org/10.1371/ journal.pone.0130005.

Plöckinger, M., Aschauer, E., Hiebl, M. R. W., \& Rohatscheka, R. (2016). The influence of individual executives on corporate financial reporting: A review and outlook from the perspective of upper echelons theory. Journal of Accounting Literature, 37, 55-75. https://doi. org/10.1016/j.acclit.2016.09.002.

Post, C., \& Byron, K. (2015). Women on Boards and Firm Financial Performance: A Meta-Analysis. Academy of Management Journal, 58(5), 1546-1571. https://doi. org/10.5465/amj.2013.0319.

Rodríguez-Domínguez, L., García-Sánchez, I., \& Gallego-Álvarez, I. (2012). Explanatory factors of the relationship between gender diversity and corporate performance. European Journal of Law and Economics, 33(3), 603-620. https://doi.org/10.1007/s10657-010-9144-4.

Reguera-Alvarado, N., de Fuentes, P., \& Laffarga, J. (2017). Does board gender diversity influence financial performance? Evidence from Spain. Journal of Business Ethics, 141(2), 337-350. https://doi.org/10.1007/s10551-0152735-9.

Richard, O. C., Kirby, S. L., \& Chadwick, K. (2013). The impact of racial and gender diversity in management on financial performance: how participative strategy making features can unleash a diversity advantage. The International Journal of Human Resource Management, 24(13), 2571-2582. https://doi.org/ 10.1080/09585192.2012.744335.

Roberson, Q. M., \& Hyeon, J. P. (2007). Examining the link between diversity and firm performance: The effects of diversity reputation and leader racial diversity. Group \& Organization Management, 32(5), 548-568. https://doi.org/10.1177/1059601106291124.

Sumedrea, S. (2016). Gender diversity and firm performance in seeking for sustainable development. Bulletin of the Transilvania University of Brasov. Series V: Economic Sciences, 9(2), 369-384.

Torchia, M., Calabro, A., \& Huse, M. (2011). Women Directors on Corporate Boards: From Tokenism to Critical Mass. Journal of Business Ethics, 102(2), 299-317. https://doi. org/10.1007/s10551-011-0815-z.

Ward, M. A., \& Forker, J. (2015). Financial Management Effectiveness and Board Gender 
Diversity in Member-Governed, Community Financial Institutions. Journal of Business Ethics, 141(2), 351-366. https://doi.org/10.1007/ s10551-015-2699-9.

Wang, Y., \& Clift, B. (2009). Is There A Business Case For Board Diversity? Pacific Accounting Review, 21(2), 88-193. https://doi. org/10.1108/01140580911002044.

Wiley, C., \& Monllor-Tormos, M. (2018). Board Gender Diversity in the STEM\&F Sectors: The Critical Mass Required to Drive Firm Performance. Journal of Leadership \& Organizational Studies, 25(3), 290-308. https://doi.org/10.1177/1548051817750535.

Yoder, J. (1991). Rethinking Tokenism: Looking beyond Numbers. Gender and Society, 5(2), 178-192. https://doi. org/10.1177/089124391005002003. doc. PaedDr. Dana Egerová, Ph.D. University of West Bohemia Faculty of Economics

Department of Business Administration and Management Czech Republic egerova@kpm.zcu.cz

Ing. Marta Nosková, Ph.D. University of West Bohemia Faculty of Economics

Department of Business Administration and Management Czech Republic mnosk@kpm.zcu.cz 


\section{Abstract}

\section{TOP MANAGEMENT TEAM COMPOSITION AND FINANCIAL PERFORMANCE: EXAMINING THE ROLE OF GENDER DIVERSITY}

\section{Dana Egerová, Marta Nosková}

Despite the growing research on the effect of top management team gender diversity on company financial performance, the results remain inconclusive. The theoretical framework guiding this study includes the upper echelons theory and critical mass theory. Under the upper echelons theory framework, the study investigates whether female participation in top management teams positively influences company financial performance. Based on critical mass theory, the study attempts to determine what percentage of women in a top management team constitutes a critical mass. Unlike most previous studies, both theories are applied to only the context of 823 small- and mediumsized enterprises (SMEs) with a workforce between 50 to 250 employees in the manufacturing sector in the Czech Republic. The findings indicate that the premises of the upper echelons theory are also applicable to SMEs. At the same time, the findings show limited support for critical mass theory. More specifically, this study does not support a linear relationship between the number of women in top management team and financial performance and only partially supports a U-shaped curvilinear relationship. The implications of the findings and suggestions for future research are also discussed. In sum, this study brings new insight to the area of gender diversity in top management and advances the gender diversity literature's understanding of the relationship between top management team composition and company financial performance. Moreover, the study provides a better understanding of the key role of a critical mass in top management teams.

Key Words: Top management team, gender diversity, financial performance, critical mass, upper echelon theory.

JEL Classification: J16, M16.

DOI: 10.15240/tul/001/2019-2-009 